\title{
ADDITUR IN GALIFORNIA-THE MEANING OF DORSEY V. BARBA
}

It frequently happens at the end of a costly jury trial in a civil action that one or both parties are dissatisfied with the amount of the verdict. Unless an expedient device is available, litigants may face the prospect of spending large amounts of money and time in a new trial, with no assurance that the results will be more satisfactory. To avoid this evil, the legal profession has constantly sought methods which would correct defects in a verdict without making further litigation necessary. ${ }^{1}$

The most promising development in this quest ${ }^{2}$ is the conditional order. ${ }^{3}$ Where a motion for new trial is made on the ground that the jury's assessment of damages was improper (excessive or inadequate), the court need not go the full length of awarding a new trial but may deny the motion on condition that the party relying on the verdict consent to a change in the award. Such an order is called remittitur if the plaintiff is permitted to agree to a decrease in the verdict and additur if the defendant is allowed to consent to an increase in the award. In both situations a new trial will be granted if consent to the change is refused. In remittitur there is pressure on plaintiff to agree to a decrease in order to avoid a new trial, added expense and the possibility of an adverse decision. In additur defendant is under similar pressure to agree to an increase. It is this pressure which often prompts parties to accept additur or remittitur and thus eliminates further litigation.

While remittitur is almost umversally accepted, additur has met considerable opposition. Until the recent decision in Dorsey v. Barba, Califorma appellate court opinions indicated additur was valid," although it was recognized that the question had not been finally settled. ${ }^{\circ}$ In the Dorsey case, however, the California Supreme Court, Justice Traynor dissenting, held that a denial of plaintiff's motion for a new trial conditioned on defendant's consent to an increase in the amount of damages constituted an impairment of plaintiff's constitutional right to a jury trial. The court dis-

\footnotetext{
1 For cases discussing the wastefulness of correcting erroneous verdicts by a complete new trial see Comment, 44 YALE. L. J. 318 (1934).

2 The validity of one device, new trials limited to the issue of damages, has been recently ruled on by the California Supreme Court. Leipert v. Honold, 240 P. 2d 288 (1952), rehearing granted Feb. 29, 1952. For a listing of other jurisdictions permitting partial new trials see Note, 98 A.L.R. 941 (1935).

3 Engle v. Farrell, 75 Cal. App. 2d 612, 171 P. 2d 588 (1946) (new trial demied on condition that plaintiff deliver a deed in escrow). Payment of costs by the moving party is frequently a condition to granting a new trial. Holtum v. Grief, 144 Cal. 521, 78 Pac. 11 (1904); Brown v. Cline, 109 Cal. 156, 41 Pac. 862 (1895).

438 A.C. 402,240 P. 2 d 604 (1952).

5 Adamson v. County of Los Angeles, 52 Cal. App. 125, 198 Pac. 52 (1921) (additur granted in condemnation proceeding; upheld on collateral attack); Blackmore v. Brennan, 43 Cal. App. 2d 280, 289, 110 P.2d 723, 728 (1941) (power of trial court respecting additur recognized as established); Secreto v. Carlander, 35 Cal. App. 2d 361, 364, 95 P. 2d 476, 477 (1939) (new trial granted where defendant refused to accept additur).

C Taylor v. Pole, 16 Cal. 2d 668, 674, 107 P.2d 614, 617 (1940) (reversed for error in assessment of damages but validity of additur order left open).
} 
pelled doubts cast on the validity of remittitur by the district court of appeal, ${ }^{7}$ but refused to accept the argument that by analogy additur is valid. ${ }^{8}$

The court failed to disapprove expressly prior California decisions upholding the power to make an additur order, but instead distinguished them on their facts and on procedural points. ${ }^{9}$ An ambiguity thereby exists in the Dorsey decision which leaves the exact position of additur in California undetermined. Because of the utility of the practice as a method of terminating litigation, it is desirable to reexamine the objections raised to the use of additur ${ }^{10}$ and to investigate the extent to which its use in California courts is now precluded.

\section{EXTENT OF ACCEPTANCE OF ADDITUR}

\section{Historical Development}

Although little can be added to the extensive discussions of the validity of additur and remittitur at common law, ${ }^{11}$ it may be helpful to trace briefly the rise of the trial court's power to control the jury's assessment of damages. Since additur and remittitur are conditional orders made on motion for a new trial based upon inadequacy or excessiveness in the amount of the verdict, they obviously did not develop until the power to grant new trials for error in the amount of the verdict had been recognized. ${ }^{12}$ At first, new trials were granted only for misconduct of the jury. Accordingly, in the first case where a new trial was granted for excessive damages, misconduct was made the basis of the decision. ${ }^{13}$ Subsequently, excessiveness itself became a sufficient ground for granting a new trial. ${ }^{14}$ However, new trials for excessive verdicts long remained limited to contract cases where damages were typically liquidated or ascertainable by a fixed formula, and did not appear in personal injury actions until shortly before $1800 .{ }^{15} \mathrm{New}$ trials for inadequacy of damages developed much more slowly along parallel lines. ${ }^{16}$

226 P. 2d 677, 688 (1951).

s Dorsey v. Barba, supra note 4 at 411,240 P.2d at 609.

9 Id. at $409 \mathrm{n}, 240$ P. $2 \mathrm{~d}$ at $608 \mathrm{n}$.

10 Discussions of remittitur and additur in legal periodicals are numerous. For general surveys see Carlin, Remittiturs and Additurs, 49 W. VA. L. Q. 1 (1942); Comment, 44 YALE L. J. 318 (1934). For notes on California cases see 28 CatIF. L. REv. 533 (1940), 14 So. CaIrF. L. Rev. 490 (1941), 3 Stan. L. Rev. 738 (1951).

II See especially Washington, Damages in Contract at Common Law, 47 L. Q. Rev. 345 (1931). On the validity of additur and remittitur from a historical perspective see text at note 49 infra.

12 Originally, the determination of damages was considered to be a matter entirely within the province of the jury. Corrections were made only in very few instances and at first took the form of outright changes by the court in bank. Washington, supra note 11 at 354 .

13. Wood v. Gunston, Sty. 466, 82 Eng. Rep. 867 (1655).

14 The procedure of appealing to the court in bank was retained even after the courts began to grant new trials for defects in the assessment of damages. 3 BLACrsrone, CoMmantaries 392 ; McCoramcK, Darrages 74 n. 14 (1935).

15 See cases cited in the dissent in Dorsey v. Barba, supra note 4 at $414 \mathrm{n.4}, 240$ P.2d at 611; Washington, supra note 11 , at 364 .

${ }_{10}$ As late as the middle of the 19th century, an English court advocated refusal of a new trial on this ground where the amount of damages could not be determined by some fixed formula. See Armytage v. Haley, 4 Q.B. 917, 114 Eng. Rep. 1143 (1843). Kentucky and Okla- 
The reluctance of courts to grant a new trial for improper assessment of damages, especially where the assessment involved exercise of discretion, was carried over into cases involving conditional orders of remittitur and additur. In England, remittitur appeared only in rare instances and no case can be found in which additur was granted. ${ }^{15}$ The impact of these conditional orders on the English court system was therefore minimal when in 1905 the House of Lords held courts had no power to change conditionally the amount of the verdict without the consent of both litigants, ${ }^{18}$ thereby eliminating remittitur and additur from English practice. In the United States, the power of the trial court to order a remittitur was recognized as early as $1822^{19}$ and today is universally accepted. ${ }^{20}$ The first additur cases appeared after the Civil War, ${ }^{21}$ and to this date only a small minority of American jurisdictions has passed upon the validity of this practice. ${ }^{22}$

\section{Additur Today}

A majority of the courts which have considered the question uphold the validity of additur.$^{23}$ Only three, however, seem to permit the practice without stringent restrictions. ${ }^{24}$ Two jurisdictions deny its validity uncondition-

homa have statutes prohibiting new trials for inadequacy of damages where the verdict equals actual pecuniary damages (special damages) suffered by the plaintiff. Kx. Codes, Crv. Prac. $\S 341$ (1948); Drury v. Franke, $247 \mathrm{Ky} .758,57$ S. W. 2 d 969 (1933) ; OKra. Srat. tit. $12 \S 652$ (1941); Rowe v. Oklahoma Ry. Co., 199 Okla. 243, 185 P.2d 194 (1947). In California statutory grounds for granting new trials, listed in CAL. CODE Crv. PROC. $\$ 657$, do not include inadequacy of damages. But the power of the trial court to grant new trials for this reason has been upheld under subdivision 6 of the section. Bauman v. San Francisco, 42 Cal. App. 2d 144, 108 P.2d 989 (1940) (insufficiency of the evidence to justify the verdict and that the verdict is against the law).

17 In Belt v. Lawes, 12 Q. B. Div. 356 (1884), the power of the court to deny a new trial on condition that plaintiff consent to a decrease in the amount of damages was upheld. Brett, M.R., recognized the basic similarity of remittitur and additur and stated, at 358 , that additur should also be within the discretion of the court. (Reversed because damages found not excessive.) In Armytage v. Haley, supra note 16, a personal injury action, a procedure analagous to additur was upheld. The plaintiff was awarded one farthing and on appeal obtained a rule to show cause why a new trial should not be had unless defendant consented to an increase in damages to $£ 105 \mathrm{~s}$. $6 \mathrm{~d}$.

${ }^{18}$ Watt v. Watt [1905] A.C. 115.

19 Blunt v. Little, 3 Fed. Cas. 760, No. 1,578 (S. D. Mass. 1822). In California remittitur was first upheld in George v. Law, 1 Cal. 363 (1851).

20 McCoranck, Damages 78, n. 9 (1935); 95 A.L.R. 1163 (1935).

21 Carr v. Minor, 42 Ill. 179 (1866); James v. Morey, 44 IIl. 352 (1867).

22 Carlin, supra note 10 , at 25 .

23 Alabama: Kraas v. American Bakeries Co., 231 Ala. 278, 164 So. 565 (1935); Delaware: Rudnick v. Jacobs, 9 Harr. 169, 197 Atl. 381 (1938); of. Stentor Electric Mfg. Co. v. Klazon Co., 125 F. 2d 820 (3rd Cir. 1942) ; Georgia: E. Tris Napier Co. v. Gloss, 150 Ga. 561, 104 S.E. 230 (1920) (additur granted on defendant's counterclaim); Illinois: cases cited supra note 20; Massachusetts: Clark v. Henshaw Motor Co., 246 Mass. 386, 140 N.E. 593 (1923) (refusal of new trial upheld where defendant stipulated to an increase in the judgment; contra: Shanahan v. Boston \& N. St. Ry. Co., 193 Mass. 412, 79 N.E. 751 (1907).

24 In New Jersey and Washington the trial court's power to increase and decrease the amount of damages is apparently treated as completely equal. Gafiney v. Illingsworth, 90 N.J. L. 490, 101 Atl. 243 (1917); Clausing v. Kershaw, 129 Wash. 67, 224 Pac. 573 (1924). In Ohio the picture is confused. In a recent case the opinion of the Ohio Supreme Court, admittedly gomg beyond the exact issue involved, suggested adoption of additur to the same extent as remittitur. Markota v. East Ohio Gas Co., 154 Ohio 546, 552, 97 N.E.2d 13, 17 (1951). Though this decision cannot be considered to overrule prior Ohio cases condemning additur (Larkin v. Ohio Electric Ry. Co, 4 Ohio App. 37, 43 (1914); cf. American Express Co. v. Bender, 20 Ohio App. 436, 152 N.E. 197 (1926)), it seems to leave the question open. 
ally, holding that both plaintiff and defendant must consent to any increase in the amount of damages. ${ }^{25}$ A United States Supreme Court decision holding additur to be beyond the power of a federal trial court ${ }^{26}$ was distinguished by the Fifth Circuit Court of Appeals, which sustained the use of additur in a condemnation proceeding. ${ }^{27}$ Wisconsin permits the practice under a special rule. ${ }^{28}$

A statistical listing of jurisdictions permitting additur, however, presents a deceptive picture of simplicity and fails to reveal the extremely confused state of the law. The real issue in all additur cases is the extent to which a trial court has the power to interfere with the amount of damages awarded by the jury. Although courts rarely make factual and procedural distinctions in ruling on the trial court's power to make an additur order, most of the decisions can be distinguished according to whether (1) the trial court assumed the traditional fact finding functions of the jury, or whether (2) the appealing party's right to trial by jury was really at issue.

\section{Ascertainable v. Discretionary Damages}

In most cases sustaining additur, damages were ascertainable by a fixed formula or were uncontested. ${ }^{29}$ In such situations the additur does not result in usurpation of the jury's traditional fact finding function, except in a formalistic sense. Plaintiff loses no material benefit if a new trial is denied, because denial is conditioned on defendant's consent to pay the only amount of damages permissible under the evidence, ${ }^{30}$ the only figure any jury would be allowed to find.

On the other hand, additur has been condemned most frequently in negligence suits where damages may be determined within a broad margin of reasonableness. ${ }^{31}$ In these actions the amount of damages is a question

25 Lorf v. City of Detroit, 145 Mich. 265, 267, 108 N.W. 661, 662 (1906); accord, Stanton v. Foley, 168 Mich. 453, 134 N.W. 466 (1912); Bradwell v. Pittsburgh \& W. E. Pass Ry. Co., $139 \mathrm{~Pa}$. 404, 20 Atl. 1046 (1891) ; cf. Raymond L. J. Riling Inc. v. Schuck, 346 Pa. 169, 29 A. 2d 693 (1943).

${ }^{26}$ Dimick v. Schiedt, 293 U.S. 474 (1935). For recent decisions in lower federal courts see Springer v. J. J. Newberry Co., 94 F. Supp. 905 (M.D. Pa. 1951) ; Macias v. Western Union Telegraph Co., 83 F. Supp. 492 (S.D. Cal. 1948). For a listing of nunierous law review notes on the Dimick case see McBaIne, Trial Practice In Civil Actions 982 (3d ed. 1952).

27 United States v. Kennesaw Mountain Battlefield Ass'n, 99 F.2d 830 (5th Cir. 1938).

28 Infra note 71 .

20 Additur has been upheld where the jury erred in calculating interest, Carr v. Minor, supra note 21; where there was error in the assessnient of rent, James v. Morey, supra note 21; or where undisputed medical bills were not allowed, Rudnick v. Jacobs, supra note 23, Krass v. American Bakeries $\mathrm{Co}$, supra note 23. For nuany other cases where the amount of damages was uncontested, hquidated or ascertainable by a fixed formula, see Carlin, supra note 10, at 26 .

30 In a California case the power of the trial court to make an additur order in a condemnation proceeding was subject to collateral attack by a taxpayer. Sustaining the validity of the order, the district court of appeal held that "the trial court possessed the power upon a motion for a new trial to amend or modify the verdict of the jury in the respect it did so as to make it conform to the evidence in the case." Adamson v. County of Los Angeles, supra note 5 at 132, 198 Pac. at 55. (Emphasis added.) Cf. Los Angeles County v. Rindge Co., 53 Cal. App. 166, 200 Pac. 27 (1921).

31 Usually the disapproval of additur has involved an award of general damages in a personal injury action. Dimick v. Schiedt, supra note 26; Leinon v. Campbell, $136 \mathrm{~Pa}$. Super. 370, 7 A. 2 d 643 (1939); Lorf v. City of Detroit, supra note 25. But cf. Gaffney v. Illingsworth, supra note 24 , Clausing v. Kershaw, supra note 24 , involving general damages where additur was upheld. 
of fact which has been traditionally left to the jury. If the court-determined increase is accepted by the defendant and plaintiff's motion for a new trial is denied, plaintiff will receive damages found by a judge rather than by a jury. It is this power of the court to redetermine the amount of damages in disposing of a motion for a new trial which is at the core of the dispute as to the validity of additur orders.

\section{Is Additur the Issue?}

The extent of the trial court's encroachment on the province of the jury is one basis for distinguishing the cases discussing additur. Another basis is the presence or absence of the constitutional issue of right to jury trial. In the typical additur situation the defendant is offered the option of consenting to the increase in the award. The plaintiff's motion for a new trial is denied if defendant exercises his option. Only if the defendant consents to the increase and the plaintiff appeals is the question of the validity of additur really presented.

Many decisions, however, purport to rule on the validity of additur where the defendant appealed either after refusal to consent to the increase or after exercising his option. ${ }^{32}$ Where the defendant refuses to consent and a new trial is granted, ${ }^{23}$ the order is clearly within the trial court's power. ${ }^{34}$ If the defendant at first consents to the increase and then appeals, ${ }^{35}$ any constitutional objections to additur have been waived..$^{36}$ Neither situation raises the issue of the validity of additur, so the general language in support of additur which such cases frequently contain may not be entitled to great weight.

While many statements supporting additur are dicta, the same is true of many disapprovals of the practice. Thus, additur has been condemned where the plaintiff was given the option either to accept a higher award or to succeed in his motion for a new trial. ${ }^{37}$ Here again no true additur is involved. The defendant is subjected to higher damages than originally assessed by the jury both without the benefit of a new trial and without

32 A good collection of such cases is to be found in Note, 32 Mrce. L. Rev. 538, 539 (1933).

33 For a typical example, see Secreto v. Carlander, where the defendant refused to consent to an increase of the damages in a personal injury suit and a new trial was granted. In affirming the trial court's action the California district court of appeal said: "The law is established in this state that as a condition for denying a motion for a new trial the trial court has the power to require the opposing party to consent to an increase of the amount of the jury's verdict to bring the amount of the verdict in conformity with the evidence." Supra note 5 at 364, 95 P.2d at $47 \%, 28$ CaLTF. L. REv. 533 (1940).

34 Dorsey v. Barba, supra note 7 at 688.

35. Thus, in Blackmore v. Brennan, supra note 5 at 289,110 P. 2 d at 728 , it was stated to be established law in California that the trial court may modify a judgment on motion for a new trial by reducing or imcreasing it conditional upon written consent of the party unfavorably affected thereby. The Secreto case, supra note 33, was cited with approval.

36 Ibid. The court pointed out that the defendant had waived his right to jury determination and stated that "either party who is prejudiced by such an order, so as to deprive him of the constitutional privilege of submitting his cause to a jury, may object to that procedure," thus indicating that plaintiff might have had a valid complaint.

${ }^{37}$ American Express Co. v. Bender, supra note 24 (additur granted to plaintiff on his own motion held error). 
having waived his right to jury determination of damages by consenting to the increase. ${ }^{38}$

Additur has also been said to be beyond the power of the trial court where the conditional increase order resulted in a reversal of a verdict $t^{39}$ or in an assessinent of damages where none had been allowed by the jury..$^{40}$ California courts have recognized that such cases do not turn on the court's power to change conditionally the amount of damages but on its lack of power to redetermine the liability issue. ${ }^{41}$ Where the verdict involves substantial error which affected determination of the merits, the defect cannot be cured and a new trial nuust be had. ${ }^{42}$

\section{ADDITUR AND THE RIGHT TO A JURY TRIAL}

Very few additur cases have arisen where plaintiff's right to a jury determination of unliquidated daniages was at issue. Dorsey v. Barba is the

38 Sigol v. Kaplan, 147 Wash. 269, 266 Pac. 154 (1928) (granting plaintiff option to accept increase in damages or new trial held error; personal injury suit).

Closely analagous are cases where the court denies a new trial and changes the aunount of the verdict without giving an option to either party. The power of the court to change the amount of the verdict outright is, however, denied even in jurisdictions where conditional additur orders are permitted. Campbell v. Sutliff, 193 Wis. 370, 214 N.W. 374 (1927) (outright increase of the amount of damages by the court from $\$ 0$ to $\$ 50$ held erroneous but not reversible because the defendant was not materially injured by the order). But of. Stagg v. Broadway Garage Co., 87 Mont. 254, 286 Pac. 415 (1930) (compulsory increase of damages by trial court upheld in property injury suit where the amount was liquidated).

Virginia's statute requires compulsory increase or decrease in the amount of the verdict where there is sufficient evidence to ascertain the amount of damages and the hability issue is determined. VA. Code tit. 8, \$ 352 (1950), Blake v. Smith, 147 Va. 960, 133 S.E. 685 (1926) (judgment increased by court in action for contract damages); Apperson Lee Motor Co. v. Ring, 150 Va. 283, 143 S.E. 694 (1928) (increase of unliquidated daniages to amount admitted by defendant held no error). The Virginia rule is discussed in Note, 26 VA. L. Rev. 836 (1940).

30 Shanahan v. Boston \& N. St. Ry. Co., supra note 23 (additur witl defendant's consent held invasion of plaintiff's constitutional rights). The court overlooked the fact that the verdict of the jury had been in favor of defendant and that therefore the additur resulted in redetermination of the liability issue. Cf. Schiedt v. Dimick, 70 F. 2d 558, 564 (1st Cir. 1934) (dissenting opinion). Occasionally such orders are upheld. Campbell v. Sutliff, supra note 38 .

40 Lorf v. City of Detroit, supra note 25 at 267,100 N.W. at 662 . See Dorsey v. Barba, supra note 7 at 686 .

41 Werner v. Bryden, 84 Cal. App. 472, 258 Pac. 138 (1927) (option to defendant to consent to judgment in favor of plaintiff where verdict was for defendant held error). Conpare Chapman v. Municipal Court, 91 Cal. App. 2d 689, 205 P.2d 712 (1949) (judgment affirmed on similar facts where defendant was appellant) ; Taylor v. Pole, supra note 6 (verdict in favor of plaintiff for $\$ 0$; trial court denied plaimtiff's motion for new trial on condition that defendant consent to paying liquidated property damages; held trial court erred in failing to allow damages for pain and suffering).

42 Jensen v. Graham, 200 Wis. 357, 228 N.W. 475 (1929) (trial court could not grant optional denial of new trial where conflict in evidence as to plaintiff's offer to complete the contract). See United States v. Kennesaw Mountain Battlefield Ass'n, supra note 27 at 834 (attempt to limit Dimick v. Schiedt, supra note 26, to cases where jury's determination of liability in doubt). Several jurisdictions do not permit additur or remittitur if the iniproper assessinent of damages indicates passion and prejudice. Wollangk v. Jurgella, 248 Wis. 178, 21 N.W.2d 272 (1946) (trial court not permitted to make an additur order where jury verdict was clearly contrary to instructions and did not allow any damages to one of the very seriously injured plamtifis); see Markota v. East Ohio Gas Co., supra note 24 at 558, 97 N.E. 2 d at 19, for a justification of this rule.

California courts may issue remittitur and additur orders even where the amount of the verdict reflects passion and prejudice. Reilley v. McIntire, 29 Cal. App. 2d 559, 85 P.2d 169 (1938) (remittitur); Secreto v. Carlander, supra note 6 (additur). 
first California case squarely presenting the validity of additur. ${ }^{43}$ The jury awarded plaintiffs $\$ 620.39$ and $\$ 1293.60$, respectively, as damages for injuries suffered in an automobile accident. These amounts constituted less than the maximum special damages allowable under the evidence and did not include any general damages for pain, suffering and permanent scarring of plaintiffs' faces. ${ }^{44}$ On plaintiffs' motion for a new trial on the ground of inadequacy of the verdict, the court made orders denying the motions on condition that defendant consent to judgments of $\$ 1500$ and $\$ 3000$. Defendant agreed to the additions and plaintiffs appealed. The First District Court of Appeal held that plaintiffs, under the evidence, were entitled to substantial general damages in addition to special damages and that the increases conditionally ordered by the court, while including some general damages, fell far short of the maximum verdict which a jury might have rendered on new trial without being reversed for awarding excessive damages. The court held that plaintiffs had been denied their constitutional right to have a jury determine the amount of damages and remanded the action for a new trial on the issue of damages alone.

The supreme court reached the same result in a decision leaming heavily on the inajority opinion of the United States Supreme Court in Dimick v. Schiedt. There, on similar facts, the United States Supreme Court held, in a five to four decision, that a federal district court had no power to make an additur order because it abridged the right to a jury trial guaranteed under the United States Constitution. ${ }^{45}$

The basis of the Dorsey opinion is that the Califorma Constitution requires the preservation of all substantive elements of jury trial as they existed at common law, ${ }^{46}$ that the final deterinination of the amount of damages by a jury is a substantive element of jury trial, and hence plaintiff's right to a jury trial is abridged where his motion for a new trial is denied on condition that defendant consent to an increase in the amount of damages. ${ }^{47}$

\section{Is Additur Theoretically Justifiable?}

Supporters of the constitutional validity of additur use three major lines of argument in supporting the practice: (1) that common law precedent supports the validity of additur; (2) that the trial court has complete discretion in ruling on a motion for new trial on the ground that the amount of the verdict is improper and therefore should have power to impose any conditions it deems justified; (3) that additur and remittitur are essentially reverse sides of the same coin, that if remittitur is upheld additur must necessarily be valid too.

\footnotetext{
43 Supra note 4.

44 The facts of the case are stated in the district court of appeal opinion, supra note 7.

45 Supra note 26. Justice Stone, joined by Chief Justice Hughes and Justices Brandeis and Cardozo, dissented.

40 "The right of trial by jury shall be secured to all, and remain inviolate." Catrf. Const. Art. I, §7.

4 Dorsey v. Barba, supra note 4 at 410,240 P. $2 d$ at 609.
} 
The first argument aims at refuting the theory that additur is contrary to the principles of jury trial as it existed at common law. ${ }^{48}$ Historical research has led to the inconclusive result that additur was unknown at common law and such research has been used in arguments both for and against additur's present validity. ${ }^{49}$ History fails to yield a satisfactory answer to the problem.

The second argument, based on the trial court's discretion in ruling on inotions for a new trial where the grounds are inadequacy or excessiveness of damages, is equally unconvincing. Judges favoring additur have argued that it is illogical to hold that a trial court has full discretion to deny a motion for new trial without giving any reason, and yet to strip it of this discretion where it denies a new trial because the error in the jury's verdict has been cured by raising the amount of the verdict. ${ }^{50}$ It is by no means certain that the power of the trial court to grant or deny a new trial on grounds of an improper assessment of damages is wholly discretionary. ${ }^{51}$ But if such discretion were in truth complete and unreviewable it does not follow that the trial court may in the exercise of its discretion impose conditions which result in depriving either party of a constitutional right. ${ }^{52}$

\section{Similarity of Additur and Remittitur}

The third argument, based on the similarity of additur and remittitur appears sound. If remittitur is valid and is not substantially distinguishable from additur, then it follows that if one is within the trial court's power the other also should be.

In disapproving additur orders courts are faced with a dilemma. They must either condemn remittitur orders and overrule a long series of precedents, or be imconsistent by permitting the practice to continue though remittitur is clearly open to the same objections as additur. In order to avoid this dilemma some courts have attempted to distinguish the two practices. Thus it has been said that in remittitur defendant's rights are not abridged because the reduced amount of the verdict is included in the larger amount found by the jury, while additur constitutes a "bald addition" ${ }^{33}$ by the court, hence a denial of plaintiff's right to jury determina-

48 See Justice Traynor's dissent in the Dorsey case, supra note 4 at $412-415,417,240$ P. 2d at $610-613,615$.

49 Compare the majority opinion in Dimick v. Schiedt, supra note 26 at 480 , with the dissent at 495 .

50 See Stone, J. in Dimick v. Schiedt, supra note 26 at 497; Traynor, J. in Dorsey v. Barba, supra note 4 at 418,240 P. $2 \mathrm{~d}$ at 614 .

51 It has been held that the trial court's discretion in disposing of motions for new trial on grounds of improper assessment of damages is not an arbitrary one. Virginian Ry. Co. v. Armentrout, 166 F.2d 400 (4th Cir. 1948) (denial of new trial, where verdict was so excessive that it could not be justified by anything in the record, held abuse of discretion analagous to error of law and reviewable as such on appeal); Bencich v. Market Street Ry. Co., 20 Cal. App. 2d 518, 67 P.2d 398 (1937) (denial of new trial on grounds of inadequacy of damages held abuse of discretion) ; cf. Covey Gas \& Oil Co. v. Chechetts, 187 F. 2d 561 (9th Cir. 1951) (remittitur order made on appeal where trial court denied new trial on grounds of excessiveness of damages).

52 Dorsey v. Barba, supra note 4 at 411,240 P. 2d at 609.

43 Dimick v. Schiedt, supra note 26 at 486 . 
tion of "a matter of fact which no jury has ever passed upon either explicitly or by implication." ${ }^{44}$ In reality, as pointed out by Professor Carlin, neither remittitur nor additur results in a judgment based upon a verdict which has been rendered by a jury. ${ }^{55}$ In neither situation can it be said that a jury has determined the amount remitted or added. In both instances the amount by which the jury award is changed is determined by the judge, who, with the consent of one litigant, substitutes his determination of damages for that of the jury. ${ }^{56}$ It is this power of the trial court to redetermine the amount of damages in a conditional order for new trial which must be reconciled with the constitutional guarantee of jury trial if additur and remittitur are to be held valid.

The United States Supreme Court has held that remittitur is within the power of the trial court because, in ruling upon a motion for new trial on grounds of excessiveness of damages, the judge necessarily determines the limits within which damages would not be considered excessive. ${ }^{5 n}$ This argument is satisfactory as far as it goes. As Chief Justice Gibson says in the Dorsey case: "It is of course, clear that there has been no denial of [the right to a jury trial] if a verdict is set aside and a motion for a new trial granted." ${ }^{\prime 8}$ But while the statement supports the court's power to set aside excessive verdicts and to grant a new trial, "it does not follow that, in lieu of ordering a new trial, the court may itself assess damages on conflicting or uncertain evidence." 50 Damages which are subject to redetermination by a court are not in fact finally determined by a jury since the court substitutes its own estimate of what the correct amount should be for that of the "chosen" finders of fact. ${ }^{60}$ This is particularly apparent where the amount of damages must be determined within a wide margin of reasonableness as in the typical negligence suit. Here the court is governed much by the same considerations which are ordinarily before a jury and is acting in effect like a one-man jury. ${ }^{61}$ If jury determination of damages is a constitutional right it must include final determination by a jury or the right is rendered meaningless. ${ }^{62}$

54 Dimick v. Schiedt, supra note 26 at 487 . An even less defensible distinction is sometimes made on the basis that in remittitur the winning plaintiff is given the option while in additur the "losing, negligent defendant" is accorded the choice. Lemon v. Campbell, supro note 31. Does this anean that a party should be denied a constitutional right because he was negligent?

55 Carlin, supra note 10 , at 25.

$56 I d$. at 27 . In remittitur as well as additur the party denied a new trial loses the same thing-a chance to a nore favorable verdict on new trial. Note, 14 So. CAIIF. L. REv. 490, 491 (1941).

57 Arkansas Cattle Co. v. Mami, 130 U.S. 69 (1889).

58 Dorsey v. Barba, supra note 4 at 410,240 P.2d at 608.

59 Id. at 411,240 P.2d at 609.

60 Proponents of the constitutional validity of additur lave said that at common law redetermination of damages by a new jury was unknown and that therefore one jury verdict satisfies the constitutional guarantee. Traynor, J. in Dorsey v. Barba, sitpra note 4 at 415, 240 P. 2 d at 611; Stone, J. in Dimick v. Schiedt, supra note 26 at 494; Note, 33 MrCH. L. REv. 138,140 (1933).

61 Carlin, supra note 10 at 29,36 . at 486 .

${ }^{62}$ Dorsey v. Barba, supra note 4 at 410,240 P. 2d at 608 ; Dimick v. Scliedt, supra note 26 


\section{Policy Justifies Additur}

It is by no means true that the limits of the constitutional right to a jury trial must be set by pre-revolutionary common law standards. Modern trial practice has dispensed with many procedural requirements of jury trial in the interest of adjusting trial practice to the requirements of modern society. ${ }^{03}$ In the days of Blackstone it was perhaps justifiable to deny trial courts the power to encroach on the province of the jury by conditionally changing the amount of the verdict. Today, however, the vast increase of the amount and complexity of litigation justifies adoption of practices which, while perhaps not wholly in accord with common law practice, permit the speedy termination of litigation without injustice to either party. If the court's power is limited to setting aside improper verdicts, litigation may continue ad infinitum because there is no assurance that the amount of damages found on new trial will not have to be set aside.

It was as much for this reason as because of the many prior decisions upholding the practice that the California Supreme Court in Dorsey $v$. $B a r b a$ again reaffirmed the validity of remittitur. ${ }^{64}$ But the same considerations of policy must govern the validity of additur, because both practices have the same purpose of terminating litigation and both present the same problems. In additur as well as in remittitur something is taken away from the successful litigant, who is relying on the jury's verdict, and is given to the adverse party. Plaintiff gives up money which was awarded him if he remits; defendant pays money not required by the terms of the verdict if he adds. As the supreme court has admitted in the Dorsey case that there is no real distinction between remittitur and additur, ${ }^{65}$ it seems impossible to refute Justice Traynor's reasoning that if one is allowed the other must necessarily be permitted. He said: "to hold remittitur constitutional and additur unconstitutional is not only illogical-it is unfair." "The majority decision in the Dorsey case, as pointed out in the dissent, results in giving the plaintiff a new trial as a matter of right while it would deny the defendant the same right in the same action if a new jury should allow plaintiff excessive damages. ${ }^{67}$

\section{Limits of the Dorsey Case}

While the Dorsey case must result in at least partial restriction of the trial court's power to grant a conditional increase in the verdict in response to a plaintiff's motion for a new trial, it does not proscribe additur as such. It prohibits it only where the plaintiff "under the evidence could have obtained a still larger award from a second jury."

This language and the facts of the case ${ }^{69}$ seem to indicate that a trial

08 Id. at 495-496.

64 Dorsey v. Barba, supra note 4 at 411,240 P. 2d at 609.

65 Ibid.

66 Id. Traynor, J., at 420,240 P. 2 d at 615.

07 Ibid.

68 Id. at 410,240 P. $2 \mathrm{~d}$ at 608 .

60 See text at note 44 supra. 
court could validly deny plaintiff's motion for a new trial on condition that defendant consent to the highest award a jury could be allowed to find. ${ }^{70}$ The plaintiff would have no complaint under such circumstances because he could not possibly receive more on second trial than the defendant has consented to pay; any higher award by a second jury would presumably be set aside as excessive. Any objections which defendant could raise would be precluded by his consent. ${ }^{71}$ The practice was impliedly approved by the district court of appeal opinion, where Judge Peters supposed that "if the defendant consent to [the] maximum figure the plaintiff could not legally object because he has received the maximum amount that the evidence would support."

A possible objection to such a rule is that a court's determination of the highest and lowest allowable limits of damages will necessarily be influenced by the amount actually found by the jury. Thus a very inadequate verdict might induce the court to set different margins of reasonability than less defective verdicts. It is hard to predict whether an extremely low verdict would impress a judge by its unreasonableness and cause him to be less conservative than warranted in setting the amount of a conditional increase, or whether he would tend to be influenced by the small amount awarded by the jury and set a lower amount than he would if he were viewing the evidence without benefit of a jury verdict. ${ }^{73}$ In the unlikely event that the psychological effect of the verdict would distort the additur to such an extent that the plaintiff would be materially injured, his rights would be protected sufficiently by the opportunity of appellate review. ${ }^{74}$

In addition to opening the way to a possible adoption of additur limited to maximum allowable amounts, the Dorsey decision seems to permit continuation of the practice of granting conditional increases of inadequate

To Several jurisdictions seem to follow a rule permitting the trial court to deny plaintiff's motion for a new trial on condition that defendant consent to the highest award recoverable by plaintiff under the evidence. Kraas v. American Bakeries, supra note 23 at 283,164 So. at 570 (general damages in personal injury suit); cf. Gaffney v. Illingsivorth, supra note 24 (option refused by defendant; grant of new trial upheld) ; compare Bingainan v. City of Seattle, 139 Wash. 68, 245 Pac. 411 (1926) (option given to plaintiff on appeal to consent to an increase of damages to the lowest estimate made by defendant's witnesses).

${ }^{71}$ This is the basic premise of the Wisconsin rule. In that state, on motion for a new trial because of inadequate or excessive damages, plaintiff as well as defendant must be given the option either to terminate further hitigation by consenting to the award most favorable to the other party that a jury could reasonably be allowed to find, or to suffer a new trial. Thus plaintiff can consent to the lowest allowable award, while the defendant is permitted to agree to the highest supportable judgment. Risch v. Lawhead, 211 Wis. 270, 248 N.W. 127 (1933) (additur to lowest adequate amount granted on plaintiff's motion); see Campbell v. Sutliff, sucpra note 38, for an extensive discussion of the historical development of the rule. The alternative option system has been held applicable to neghigence suits involving madequate special damages, Wollangk v. Jurgella, supra note 42 , and is used on the trial as well as on the appellate level. Rueping v. Chicago \& N. W. Ry. Co., 123 Wis. 313, 101 N.W. 710 (1904) (remittitur order issued on appeal). The rule is well discussed in Note, 27 MarQ. L. REv. 86 (1943).

72 Dorsey v. Barba, supra note 7 at 690 . The supreme court opinion mentions the Wisconsin rule without comment.

73 The same considerations would be applicable to an extremely excessive verdict if the same limitation were to be apphed to remittitur orders, i.e., requiring the judge to set the option to remit at the lowest possible amount that a jury would be allowed to find.

$7 \pm$ Markota v. East Ohio Gas Co., supra note 24 at 557, 97 N.E. 2d at 19. 
judgments where the amount of damages is uncontested or ascertainable by a fixed formula. Decisions upholding additur in such situations are distinguished in the Dorsey case and should continue to constitute good precedent. ${ }^{75} \mathrm{~A}$ court is not really assuming a jury function when it permits the defendant to consent to an increase in damages to the only amount any jury would be allowed to find. ${ }^{76}$

\section{CONCLUSIONS}

In Dorsey v. Barba the California Supreme Court announces a rule which must lead to considerable restriction of trial courts' power to issue additur orders, while leaving their long established power to make remittitur orders completely undisturbed. The decision results in curtailing a valuable practice conducive to early termination of litigation and therefore must be deplored. Furthermore, it results in giving a plaintiff an unfair advantage over a defendant whenever a motion for a new trial on grounds of improper damages is at issue.

The defendant would not even be restored to a fully equal position with the plaintiff if the Dorsey case should pave the way for the adoption of additur limited to maximum allowable amounts, as there is no indication that remittitur would be similarly limited. ${ }^{77}$ To avoid a new trial on the issue of damages, the plaintiff, under remittitur, need consent only to a decrease of the award which would make it no longer excessive.

On the other hand, defendant, under a form of limited additur, would have to consent to the highest allowable award in favor of plaintiff in order to defeat a motion for a new trial on grounds of inadequacy of damages.

Though the maximum allowable amount option may be sustained theoretically, it offers little practical inducement to the defendant, who, but for additional court costs, could lose little more by being subjected to a new trial than by consenting to the increase. This circumstance would tend to defeat the prime purpose of additur-termination of litigation. ${ }^{78}$

Additur cannot be restored to its full usefulness short of a complete overruling of Dorsey or a constitutional amendment. A statutory correction of the result of the Dorsey case seems precluded because it would be subjected to the same constitutional objections as the procedure condemned there. ${ }^{\text {t9 }}$

Harry J. Keaton

75 Dorsey v. Barba, supra note 4 at 409 n., 240 P. $2 d$ at 608 n.

${ }^{76}$ See Rudnick v. Jacobs, supra note 23 at 177,197 Atl. at 382 (1938).

T7 Hepner v. Libby, McNeil \& Libby, 114 Cal. App. 747, 300 Pac. 830 (1931) (trial court need not fix lowest possible sum which another jury could award).

78 MCCormick, DaMaAes 83 (1935).

79 Dorsey v. Barba, supra note 4 at 412,240 P. $2 d$ at 609. 